\title{
Acyl-Protein Thioesterase 1
}

National Cancer Institute

\section{Source}

National Cancer Institute. Acyl-Protein Thioesterase 1. NCI Thesaurus. Code C104626.

Acyl-protein thioesterase 1 (230 aa, $25 \mathrm{kDa}$ ) is encoded by the human LYPLA1 gene.

This protein plays a role in regulating membrane lysophospholipid levels. 